\title{
Toxigenic profile of methicillin-sensitive and resistant Staphylococcus aureus isolated from special groups
}

\author{
Camila Sena Martins de Souza ${ }^{1,2}$, Carlos Magno Castelo Branco Fortaleza², \\ Claudia Lima Witzel 1,2, Mônica Silveira², Mariana Fávero Bonesso 1,2, Silvio Alencar Marques ${ }^{3}$ \\ and Maria de Lourdes Ribeiro de Souza da Cunha ${ }^{1,2^{*}}$
}

\begin{abstract}
Background: Staphylococcus aureus is characterized by its pathogenicity and high prevalence, causing disease in both healthy and immunocompromised individuals due to its easy dissemination. This fact is aggravated by the widespread dissemination of $S$. aureus carrying toxigenic genes. The objective of this study was to determine the toxigenic profile of methicillin-sensitive S. aureus (MSSA) and methicillin-resistant S. aureus (MRSA) in patients with purulent skin and/or soft tissue infections seen at the Dermatology Department of the University Hospital of the Botucatu Medical School, asymptomatic adults older than 60 years living in nursing homes, and prison inmates of the Avaré Detention Center.

Methods: PCR was used for the detection of the mecA gene, enterotoxin genes (sea, seb, and sec), exfoliative toxins A and B (eta and etb), toxic shock syndrome toxin 1 (tst), panton-valentine leukocidin (lukS-PV and lukF-PV), and alphaand delta-hemolysins or cytotoxins ( $h / a$ and $h / d$ ).

Results: The results showed a significant prevalence of toxigenic genes among S. aureus isolates from asymptomatic individuals, with the observation of a higher prevalence of cytotoxin genes. However, the panton-valentine leukocidin gene was only detected in MSSA isolated from patients with skin infections and the tst gene was exclusively found in MSSA isolated from prison inmates.
\end{abstract}

Conclusions: The present study demonstrated a significant prevalence of toxigenic genes in MSSA and MRSA strains isolated from asymptomatic $S$. aureus carriers. There was a higher prevalence of cytotoxin genes.

Keywords: Staphylococcus aureus, MSSA, Toxins, Cytotoxins

\section{Background}

Staphylococcus aureus is one of the pathogens most frequently isolated from nosocomial and communityacquired infections and represents a major public health problem because it easily acquires resistance to commonly used antibiotics. Skin and soft tissue infections (SSTI) are common bacterial infections in humans and treatment is difficult because of the increasing frequency

\footnotetext{
*Correspondence: cunhamlr@ibb.unesp.br

${ }^{2}$ Department of Tropical Diseases, Botucatu School of Medicine,

University Hospital, UNESP-Univ Estadual Paulista, Botucatu, SP, Brazi

Full list of author information is available at the end of the article
}

of methicillin-resistant S. aureus (MRSA) in the community $[1,2]$.

Nursing homes have been recognized as reservoirs of $S$. aureus. This fact is a consequence of the advanced age of elderly people, lifestyle, need for invasive devices, presence of chronic wounds, dependence on healthcare workers, and previous hospitalization. Through direct contact, MRSA colonization within nursing homes results in spread to other residents, relatives, and healthcare workers. In addition, the elderly population represents a vulnerable group that is often hospitalized. This leads to the dissemination of the microorganism within 
hospitals, which renders control measures in the open community ineffective $[3,4]$.

SSTI secondary to $S$. aureus are notorious in the prison setting. The sharing of personal items and lack of hygiene within this crowded environment facilitates the propagation and transmission of $S$. aureus between inmates and their visitors from the community [5].

After entering the host, infection develops when a pathogen escapes recognition and destruction by the host's immune system. For this purpose, S. aureus expresses different virulence factors that promote survival and pathogenesis within a host [6]. Methicillinsensitive $S$. aureus (MSSA) plays an important role by carrying virulence factors that increase its capacity for invasion and survival. In addition, MSSA has been suggested to give origin to MRSA strains by acquiring the $m e c A$ gene from coagulase-negative staphylococci found on the skin of healthy individuals.

The objective of this study was to determine the toxigenic profile of MSSA and MRSA isolated from nursing home residents, prison inmates, and patients with purulent SSTI.

\section{Experimental section Strains}

A total of 150 S. aureus strains were analyzed. The samples included in this study were obtained from three previous studies aimed at determining the prevalence of $S$. aureus [24-26]. Fifty $S$. aureus strains were isolated from 302 prison inmates between February 2009 and March 2010 [24]. The inclusion criterion was a minimum prison stay of 3 months. The study excluded individuals who utilized antibiotics during 30 days prior to sample collection. Also excluded were patients who were admitted to a hospital and those that underwent invasive procedure in the year preceding sample collection.

In addition, $50 \mathrm{~S}$. aureus strains isolated from patients with purulent SSTI treated at the Dermatology outpatient clinic of the University Hospital of the Botucatu Medical School (HC-FMB), São Paulo, Brazil, between 2008 and 2009 were included. Exclusion criteria were the same in the study with inmates. The prevalence study [25] included 127 patients from which 66 (56.9 \%) S. aureus isolates were obtained. However, since the aim of this study was to compare the virulence of $S$. aureus from different populations, we selected randomly 50 isolates to match the number of strains isolated from inmates.

The final 50 strains were randomly selected among 52 S. aureus strains isolated from 300 older adults living in seven nursing homes in Bauru, São Paulo, Brazil, in 2011 and 2012 [26]. All adults older than 60 years who agreed to participate in the study were included, regardless of their health status. Institutionalized individuals with less than 30 days were excluded.

\section{Phenotypic and genotypic identification}

The swabs were seeded on Baird-Parker agar and typical colonies were submitted to Gram staining for analysis of purity and observation of colony morphology. Catalase, coagulase and additional biochemical tests (trehalose, maltose, and mannitol) were used for the identification of S. aureus $[15,16]$.

The isolates were also submitted to genotypic identification using the SA442 primer, which is specific for $S$. aureus [17].

\section{Detection of methicillin resistance}

The $m e c A$ gene was detected by the polymerase chain reaction (PCR) [18]. International references strains were included in all reactions as positive ( $S$. aureus ATCC 33591) and negative controls (S. aureus ATCC 25923).

\section{Detection of toxin genes}

PCR was used to detect genes that encode the following toxins: classical enterotoxins (sea, seb, and sec-1) [19, 20], panton-valentine leukocidin (PVL) (lukPV) [21], toxic shock syndrome toxin $1(t s t)[19,20]$, exfoliative toxins A and B (eta and $e t b)$ [22], and cytotoxins (hla and hld) [23].

\section{Visualization of amplified products}

The efficiency of amplification was evaluated by electrophoresis on $2 \%$ agarose gel prepared in $1 \times$ TBE buffer and stained with SYBR Safe. The size of the amplified product was compared to a 100-bp standard and the gel was photographed under UV transillumination.

\section{Results}

Among the $150 \mathrm{~S}$. aureus strains studied, 20 (13.3 \%) were carriers of the mecA gene. Of these, 11 samples were isolated from nursing home residents, while 2 were obtained from inmates. The remaining 7 were isolated from patients with SSTI. The results of all genes encoding various toxins within each subgroup are summarized in Table 1. Sixty-three isolates ( $35.3 \%)$ did not carry any of the enterotoxin genes, while 87 (58 \%) carried at least one gene. Three cases notably harbored three enterotoxin genes (one collected from the Dermatology clinic versus two obtained from inmates). No differences in cytotoxin genes were observed between MRSA and MSSA isolates. The genes encoding PVL were evidently restricted to isolates obtained from the subgroup of patients with purulent SSTI. Some of the amplified genes can be observed in Fig. 1. 
Table 1 Investigation of genes encoding superantigens in the MRSA and MSSA isolates

\begin{tabular}{|c|c|c|c|c|c|c|c|c|c|}
\hline \multirow[t]{2}{*}{ Origin } & \multicolumn{3}{|c|}{ Enterotoxin } & \multicolumn{2}{|l|}{ Exfoliatin } & \multirow{2}{*}{$\begin{array}{l}\text { TSST-1 } \\
\text { tst }\end{array}$} & \multicolumn{2}{|c|}{ Hemolysin } & \multirow{2}{*}{$\begin{array}{l}\text { PVL } \\
\text { pvl n (\%) }\end{array}$} \\
\hline & sea $n(\%)$ & seb n (\%) & sec-1 n (\%) & eta $n(\%)$ & etb $n(\%)$ & & hla n (\%) & hld n (\%) & \\
\hline \multicolumn{10}{|l|}{ Nursing home } \\
\hline $\operatorname{MRSA}(n=11)$ & $6(54.5)$ & $1(9)$ & 0 & 0 & 0 & 0 & $11(100)$ & $11(100)$ & 0 \\
\hline MSSA $(n=39)$ & $16(41)$ & $14(36)$ & $2(5.1)$ & 0 & 0 & 0 & $39(100)$ & $39(100)$ & 0 \\
\hline \multicolumn{10}{|l|}{$C R$} \\
\hline $\operatorname{MRSA}(n=2)$ & 0 & 0 & 1 & 0 & 0 & 0 & $2(100)$ & $2(100)$ & 0 \\
\hline MSSA $(n=48)$ & $16(33.3)$ & $13(27)$ & 7 (14.6) & $2(4.1)$ & 0 & $5(10.4)$ & 47 (97.9) & 47 (97.9) & 0 \\
\hline \multicolumn{10}{|l|}{ Dermatology } \\
\hline $\operatorname{MRSA}(n=7)$ & $2(28.5)$ & $1(14.2)$ & 0 & 0 & 0 & 0 & $6(85.7)$ & $5(71.4)$ & 0 \\
\hline MSSA $(n=43)$ & $16(37.2)$ & $9(21)$ & $8(18.6)$ & $1(2.3)$ & 0 & 0 & $39(90.7)$ & 39 (90.7) & $10(23.6)$ \\
\hline
\end{tabular}

CR Centro de Ressocialização de Avaré (Detention Center), MRSA methicillin-resistant Staphylococcus aureus, MSSA methicillin-sensitive Staphylococcus aureus, TSST-1 toxic shock syndrome toxin 1,PVL panton-valentine leukocidin

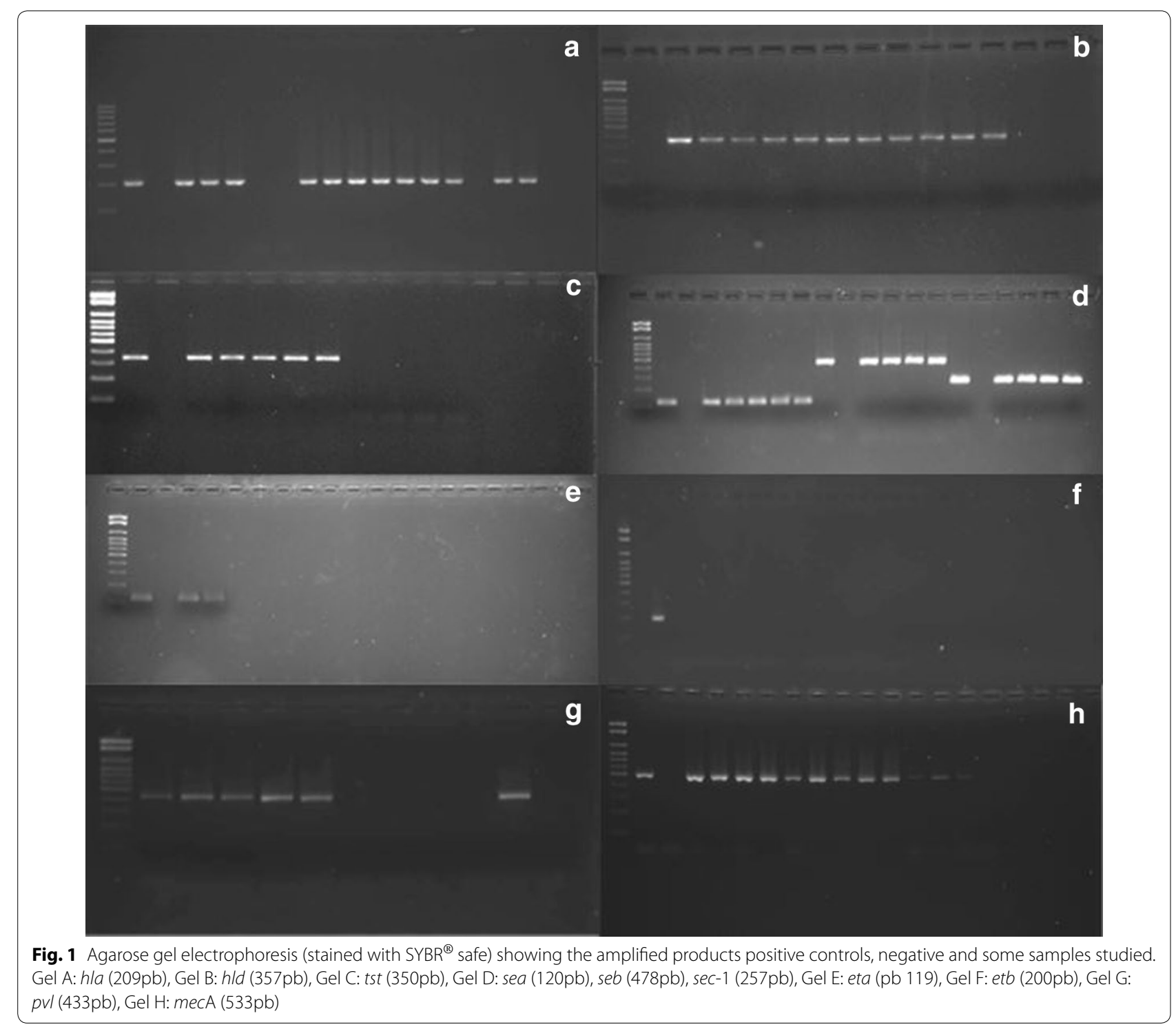




\section{Discussion}

The genotypic toxigenic profile of the isolates studied differed according to their origin. The results showed a higher prevalence of the enterotoxin A gene in all strains studied. Previous studies also reported a higher prevalence of the sea gene compared to the other enterotoxin genes in $S$. aureus isolated from hospitalized patients $[7,8]$. However, the higher prevalence of this gene in $S$. aureus isolated from healthy subjects is a new finding. Furthermore, $10 \%(n=5)$ of the isolates from the Detention Center harbored the toxic shock syndrome toxin 1 gene, whereas this gene was not detected in any of the isolates from the nursing homes or Dermatology clinic. The presence of these super antigen genes in MRSA and MSSA isolated from patients and healthy subjects implies the possibility of increased bacterial dissemination and more severe infections, since these toxins induce the activation of $\mathrm{T}$ cells and exacerbated secretion of cytokines, causing episodes of severe sepsis [9].

Different virulence factors are implicated in the pathogenesis of $S$. aureus, including exfoliatins. The eta gene was detected in $4 \%(n=2)$ of isolates from the Detention Center and in only one patient from the Dermatology clinic. The latter patient had bullous impetigo at the time of sample collection, indicating a possible expression of the eta gene by the bacterium. However, the etb gene was not detected in any isolate. This finding agrees with another study in which MRSA and MSSA isolated from a tertiary hospital did not harbor the exfoliatin B gene [8].

Colonization with $S$. aureus is a characteristic feature of several inflammatory skin diseases, which is often followed by epidermal damage and invasive infection. This damage is the result of the dermonecrotic activity of cytotoxins [10]. Alpha-cytotoxin acts by forming pores in the target membrane and delta-cytotoxin acts as a surfactant. The two cytotoxins or hemolysins are involved in erythrocyte lysis [11]. The present results demonstrate a high prevalence of alpha- and delta-cytotoxin genes in MSSA and MRSA isolates of all origins. Therefore, hemolytic activity is paramount to an organism's virulence and its capacity for pathogenesis since the resulting degradation of host tissue permits invasion, dissemination, and escape from the immune system [12].

Investigation of the $p v l$ gene revealed the presence of $p v l$ gene-positive $S$. aureus only in patients of the Dermatology clinic $(n=10,20 \%)$. These strains were isolated from primary and secondary infections. A study in the United Kingdom that examined 65 nursing homes similarly did not detect the $p v l$ gene. However, in the present study, none of the MRSA isolates carried the $p v l$ gene, thus refuting the suggestion that this gene is a good marker of MRSA strains [4]. Our results are in agreement with previous studies that have demonstrated lysogeny of MSSA a phage that harbors $p v l$ genes and subsequently acquires the mecA gene [13]. Other studies have similarly identified MRSA strains that lacked genes encoding $p v l$ [14].

A strength of this study is the comparison of the presence of several genes encoding virulence factors (enterotoxins, exfoliatins, TSST-1, cytotoxins, and PVL) between MSSA and MRSA from different populations. However, a limitation was the fact that only the presence of these genes was investigated. Future studies evaluating the expression of these virulence factors are therefore important. Knowledge of the pathogenic profile of $S$. aureus permits a better understanding and control of this microorganism, which has become one of the main causative agents of healthcare-associated infections.

The present study demonstrated a significant prevalence of toxigenic genes in MSSA and MRSA strains isolated from asymptomatic $S$. aureus carriers, with the observation of a higher prevalence of cytotoxin genes. These results are important and indicate the need for further case-control or cohort studies to determine the role of these toxins in the occurrence of staphylococcal infections.

\section{Availability of supporting data}

The data set supporting the results of this article is included in the article.

\section{Abbreviations}

MRSA: methicillin-resistant Staphylococcus aureus; mecA: methicillin resistance gene; sea: staphylococcal enterotoxin A; seb: staphylococcal enterotoxin B; sec: staphylococcal enterotoxin C; eta: exfoliative toxin A; etb: exfoliative toxin B; luk-PV: panton-valentine leukocidin; tst: toxic shock syndrome toxin 1; hla: alpha-hemolysin; hld: delta-hemolysin; PCR: polymerase chain reaction; HCFMB: University Hospital of the Botucatu Medical School; CR: detention center.

\section{Authors' contributions}

CSMS participated in the conception and design of the study, carried out the microbiological tests, and participated in the writing of the paper. CMCBF participated in the conception and design of the study. CLW contributed materials. MS contributed materials. MFB contributed materials. SAM contributed materials. MLRSC responsible for the conception and design of the study and participated in the writing of the paper. All authors read and approved final manuscript.

\section{Author details}

${ }^{1}$ Department of Microbiology and Immunology, Botucatu Biosciences Institute, UNESP-Univ Estadual Paulista, Botucatu, SP, Brazil. ${ }^{2}$ Department of Tropical Diseases, Botucatu School of Medicine, University Hospital, UNESPUniv Estadual Paulista, Botucatu, SP, Brazil. ${ }^{3}$ Department of Dermatology and Radiology, Botucatu School of Medicine, University Hospital, UNESP-Univ Estadual Paulista, Botucatu, SP, Brazil.

\section{Acknowledgements}

We thank Coordenação de Aperfeiçoamento de Pessoal de Nível Superior (CAPES) and Conselho Nacional de Desenvolvimento Científico e Tecnológico (CNPq) for financial support.

\section{Competing interests}

The authors declare that they have no competing interests. 
Received: 10 September 2015 Accepted: 3 February 2016 Published online: 16 February 2016

\section{References}

1. Eckmann C, Dryden M. Treatment of complicated skin and soft-tissue infections caused by resistant bacteria: value of linezolid, tigecycline, daptomycin and vancomycin. Eur J Med Res. 2010;15:554-63.

2. Adhikari RP, Ajao AO, Aman MJ, Karauzum H, Sarwar J, Lydecker AD, et al Lower antibody levels to Staphylococcus aureus exotoxins are associated with sepsis in hospitalized adults with invasive S. aureus infections. J Infect Dis. 2012;206(6):915-23. doi:10.1093/infdis/jis462.

3. Pfingsten-Wurzburg S, Pieper DH, Bautsch W, Probst-Kepper M. Prevalence and molecular epidemiology of methicillin-resistant Staphylococcus aureus in nursing home residents in northern Germany. J Hosp Infect. 2011;78:10812.

4. Horner C, Parnell P, Hall D, Kearns A, Heritage J, Wilcox M. Methicillinresistant Staphylococcus aureus in elderly residents of care homes: colonization rates and molecular epidemiology. J Hosp Infect. 2013;83:212-8.

5. Cohen PR. Cutaneous community-acquired methicillin resistant Staphylococcus aureus infection in participants of athletic activities. South Med J. 2005;98:596-602.

6. Malachowa N, Kobayashi SD, DeLeo FR. Community-associated methicillin-resistant Staphylococcus aureus and athletes. Phys Sportsmed. 2012;40:13-21.

7. Ghaznavi-Rad E, Nor Shamsudin M, Sekawi Z, Khoon LY, Aziz MN, Hamat RA, Othman N, Chong PP, van Belkum A, Ghasemzadeh-Moghaddam H, Neela V. Predominance and emergence of clones of hospital-acquired methicillin-resistant Staphylococcus aureus in Malaysia. J Clin Microbiol. 2010;48:867-72.

8. Lim KT, Yeo CC, Suhaili Z, Thong KL. Comparison of methicillin-resistant and methicillin-sensitive Staphylococcus aureus strains isolated from a tertiary hospital in Terengganu, Malaysia. J Infect Dis. 2012;65:502-9.

9. Karauzum H, Chen G, Abaandou L, Mahmoudieh M, Boroun AR, Shulenin S, Devi VS, Stavale E, Warfield KL, Zeitlin L, et al. Synthetic human monoclonal antibodies toward staphylococcal enterotoxin b (SEB) protective against toxic shock syndrome. J Biol Chem. 2012;287:25203-15.

10. Katayama Y, Baba T, Sekine M, Fukuda M, Hiramatsu K. Beta-hemolysin promotes skin colonization by Staphylococcus aureus. J Bacteriol. 2013;195:1194-203.

11. Verdon J, Girardin N, Lacombe C, Berjeaud JM, Hechard Y. Deltahemolysin, an update on a membrane-interacting peptide. Peptides. 2009;30:817-23.

12. Lo CW, Lai YK, Liu YT, Gallo RL, Huang CM. Staphylococcus aureus hijacks a skin commensal to intensify its virulence: immunization targeting betahemolysin and camp factor. J Invest Dermatol. 2011;131:401-9.

13. Boyle-Vavra S, Daum RS. Community-acquired methicillin-resistant Staphylococcus aureus: the role of panton-valentine leukocidin. Lab Invest. 2007;87(1):3-9. doi:10.1038/labinvest.3700501.
14. Chen FJ, Siu LKK, Lin JC, Wang CH, Lu PL. Molecular typing and characterization of nasal carriage and community-onset infection methicillinsusceptible Staphylococcus aureus isolates in two Taiwan medical centers. BMC Infect Dis. 2012;12:2-8.

15. Konemann EW, Allen SD, Dowell VR, Sommer HM. Diagnóstico microbiológico: texto e atlas colorido. 5th ed. Medsi. Rio de Janeiro: Brasil; 2001. p. 571-8.

16. Cunha MLRS, Sinzato YK, Silveira LVA. Comparison of methods for the identification of coagulase negative Staphylococci. Mem Inst Oswaldo Cruz. 2004;99:855-60.

17. Martineau F, Picard FJ, Roy PH, Ouellette M, Bergeron MG. Species-specific and ubiquitous-dna-based assays for rapid identification of Staphylococcus aureus. J Clin Microbiol. 1998;36:618-23.

18. Murakami K, Minamide W, Wada K, Nakamura E, Teraoka H, Watanabe S. Identification of methicillin-resistant strains of staphylococci by polymerase chain reaction. J Clin Microbiol. 1991;29:2240-4.

19. Cunha MLRS, Peresi E, Calsolari RAO, Júnior JPA. Detection of enterotoxins genes in coagulase-negative staphylococci isolated from foods. Braz J Microbiol. 2006;37:70-4.

20. Johnson WM, Tyler SD, Ewan EP, Ashton FE, Pollard DR, Rozee KR. Detection of genes for enterotoxins, exfoliative toxins, and toxic shock syndrome toxin 1 in Staphylococcus aureus by the polymerase chain reaction. J Clin Microbiol. 1991;29:426-30.

21. Tristan A, Bes M, Meugnier H, Lina G, Bozdogan B, Courvalin P, Reverdy ME, Enright MC, Vandenesch F, Etienne J. Global distribution of panton valentine leukocidin-positive methicillin-resistant Staphylococcus aureus, 2006. Emerg Infect Dis. 2007;13:594-600.

22. Koning S, van Belkum A, Snijders S, van Leeuwen W, Verbrugh H, Nouwen J, et al. Severity of nonbullous Staphylococcus aureus impetigo in children is associated with strains harboring genetic markers for exfoliative toxin B, panton-valentine leukocidin, and the multidrug resistance plasmid pSK41. J Clin Microbiol. 2003;41(7):3017-21. doi:10.1128/ jcm.41.7.3017-3021.2003.

23. Marconi C, Cunha MLRS, Araújo JP Jr, Rugolo LMSS. Standardization of the PCR technique for the detection of delta toxin in Staphylococcus spp. J Venom Anim Toxins incl Trop Dis. 2005;11:117-28.

24. Witzel CL, Fortaleza CMCB, Souza CSM, Riboli DFM, Cunha MLRS. Nasopharyngeal carriage of Staphylococcus aureus among imprisoned males from Brazil without exposure to healthcare: risk factors and molecular characterization. Ann Clin Microbiol Antimicrob. 2014;13:1-6.

25. Bonesso MF, Marques SA, Camargo CH, Fortaleza CMCB, Cunha MLRS. Community-associated methicillin-resistant Staphylococcus aureus in non-outbreak skin infections. Braz J Microbiol. 2014;45:1401-7.

26. Silveira M. Prevalência e fatores de risco para carreamento de Staphylococcus aureus resistente à meticilina em idosos institucionalizados na cidade de Bauru-SP. 2013. 103p. Dissertation. Universidade Estadual Paulista Júlio de Mesquita Filho, Botucatu.

\section{Submit your next manuscript to BioMed Central and we will help you at every step:}

- We accept pre-submission inquiries

- Our selector tool helps you to find the most relevant journal

- We provide round the clock customer support

- Convenient online submission

- Thorough peer review

- Inclusion in PubMed and all major indexing services

- Maximum visibility for your research

Submit your manuscript at www.biomedcentral.com/submit

\section{Biomed Central}

